УдК : 316.7

\title{
СОЦІАЛЬНІ НАПРУЖЕННЯ В КУЛЬТУРНІЙ СФЕРІ: ІСТОРІЯ, СУЧАСНИЙ СТАН ТА ТРАНСКУЛЬТУРНІ вПливИ
}

\section{Шевель Інна Петрівна}

кандидат соціологічних наук, доцент,

Київський національний університет культури і мистещтв,

м. Київ, Украӥна

ORCID 0000-0002-6387-2506

shevelinna@ukr.net
Надіслано:

27.10.2019

Рецензовано:

15.11.2019

Прийнято:

29.11.2019

Головною проблемою сучасної науки про культуру є вивчення понять культурної комунікації, акультурації, інкультурації, мультикультуралізуму. Саме під впливом соціального оточення ці поняття проходять процес соціалізації у індивідів до культурного життя в цивілізованому суспільстві. Метою дослідження $\epsilon$ науково-теоретичне обгрунтування особливостей розвитку культурної комунікації в суспільстві та його соціальні зміни завдяки аналізу та порівнянню різноманітних підходів до вивчення їх культурної взаємодії. Методологія дослідження полягає у аналітичному аналізу вивчення культурної комунікації на появи соціальних напруг в суспільстві. Аналіз надає можливість показати і проаналізувати еволюцію культурної комунікації, прослідкувати сутність культурних понять та динаміки їх розвитку. Наукова новизна одержаних результатів полягає в тому, що в статті аналітично досліджено природу видів понять культурної комунікації та мільтикультуралізму з боку соціальних напруг в культурній сфері та увага приділяється на вивчення двох напрямків проблем культури - соціальному та культурологічному. Як видно, всі культурні моделі чи культурні коди збагачуються та модернізуються і проникають у соціальні процеси суспільства. Сьогодні ми можемо бачити, що людська культура постійно запозичує різні зразки і штампи культури і глобалізація нав'язує ці стандарти суспільству і призводить до суперечностей та напруження серед населення у культурному обміні чи взаємодії, це також відбуваються і в світових цивілізаціях, те, що вони пережили в соціально-культурних змінах, то ми отримуємо як глобалізаційний спадок. Висновок: культура становить рушійну силу для стабілізації політичних, соціальних, культурологічних процесів у суспільстві й виконує важливу соціальну роль. Культурна глобалізація стає як комплекс всіх взаємопов'язаних процесів, оптимізації культурної комунікації і зразків національної культури. 
Ключові слова: культура; культурна комунікація; інкультурація; акультурація; мультикультуралізм; культурні зразки; культурні напруження.

Shevel Inna, Candidate of Sociological Sciences, Associate Professor, Kyiv National University of Culture and Arts, Kyiv, Ukraine

Social Struggles in the Cultural Sphere: History, Modern State, and Transcultural Influence

The main problem of contemporary science of culture is the study of such concepts as cultural communication, acculturation, inculturation, multiculturalism. It is under the influence of the social environment that these concepts go through the process of socialization among individuals to cultural life in a civilized society. The purpose of the research is to provide scientific and theoretical substantiation of the peculiarities of the cultural communication development within society and its social changes through the analysis and comparison of various approaches to studying their cultural interaction. The research methodology consists in the analytical analysis of the cultural communication study on the emergence of social tensions in society. The analysis provides an opportunity to show and analyze the evolution of cultural communication, to follow the essence of cultural concepts and the dynamics of their development. The scientific novelty of the results obtained is that the article analytically analyses the nature of the types of notions of cultural communication and multiculturalism from the side of social tensions in the cultural sphere and pays attention to the study of two directions of the problems of culture social and culturological. It can be seen that all cultural models or cultural codes are enriched and modernized and penetrate the social processes of society. Today, we can see that human culture constantly borrows various patterns and cultural stamps, and globalization imposes these standards on society, leading to contradictions and tensions among the population in cultural exchange or interaction, which also occurs in world civilizations. What they experienced socially cultural changes that we get as a globalized inheritance. Conclusion: culture is a driving force for the stabilization of political, social, cultural and cultural processes in society and plays an important social role. Cultural globalization becomes a complex of all interconnected processes, optimization of cultural communication and examples of national culture.

Key words: culture; cultural communication; inculturation; acculturation; multiculturalism; cultural samples; cultural tensions. 
Міжнародні відносини: теоретико-практичні аспекти

Випуск 5 (2020)

ISSN (print) 2616-745X; ISSN (online) 2616-7794

Шевель Инна Петровна, кандидат социологических наук, доцент, Киевский национальный университет культуры и искусств, г. Киев, Украина

\section{Социальные напряжения в культурной сфере: история, современное состояние и транскультурное влияние}

Главной проблемой современной науки о культуре является изучение понятий культурной коммуникации, аккультурации, инкультурации, мультикультурализму. Именно под влиянием социального окружения эти понятия проходят процесс социализации у индивидов к культурной жизни в цивилизованном обществе. Целью исследования является научнотеоретическое обоснование особенностей развития культурной коммуникации в обществе и его социальные изменения благодаря анализу и сравнению различных подходов к изучению их культурного взаимодействия. Методология исследования заключается в аналитическом анализе изучения культурной коммуникации на появления социальных напряжений в обществе. Анализ позволяет показать и проанализировать эволюцию культурной коммуникации, проследить сущность культурных понятий и динамики их развития. Научная новизна исследования заключается в том, что в статье аналитически исследована природа видов понятий культурной коммуникации и мильтикультурализма со стороны социальных напряжений в культурной сфере и внимание уделяется на изучение двух направлений проблем культуры - социальной и культурологической. Как видно, все культурные модели или культурные коды обогащаются и модернизируются и проникают в социальные процессы общества. На сегодняшний день мы можем видеть, что человеческая культура постоянно заимствует различные образцы и штампы культуры и глобализация навязывает эти стандарты обществу, и приводит к противоречиям и напряжения среди населения в культурном обмене или взаимодействия, это также происходят и в мировых цивилизациях, то, что они пережили в социально-культурных изменениях, то мы получаем как глобализационное наследство. Вывод: культура составляет движущую силу для стабилизации политических, социальных, культурологических процессов в обществе и выполняет важную социальную роль. Культурная глобализация становится как комплекс всех взаимосвязанных процессов, оптимизации культурной коммуникации и образцов национальной культуры.

Ключевые слова: культура; культурная коммуникация; инкультурация; аккультурация; мультикультурализм; культурные образцы; культурные напряжения. 


\section{Вступ}

У культурній практиці сьогодення відбуваються трансформаційні соціальні зміни, які орієнтуються на збереження та розвиток національної культури. 3 політичними змінами, які відбулися в нашій країні за останні роки дуже вдало видно як стрімко відбулося саме національне відродження культури. Серед наукових доробок сучасних трансформаційних процесів угалузі культури, велика увага приділяється аналізу та вивченню історії української культури та їх соціальних змін у глобалізаційний період та аналіз сучасного стану культурного процесу суспільства та в житті людей. Коли проаналізувавши історичну літературу, то можемо побачити, що аналіз безпосередньо відбувався на традиційно-побутовій сфері життя людей. Формувалися звичаї, традиції, культурні пам'ятки, мистецтво і як все це проходило еволюцію розвитку, відбувалися соціальні зміни і глобалізаційні перетворення, культурні напруження і знаходили свою нішу в сьогоденній культурі нашого суспільства. Один із перших почав вивчати структуру культури Е. Хобель (американський дослідник), також вивчав поняття культурний елемент, який пов'язував з поведінковим взірцем започаткований на традиції (Sakharchuk, 2009, pp.314-317). Структура будь-якої культури формується з багатьох елементів і складає одне ціле загальної культури. Спосіб життя людини формується завдяки звичкам, стереотипам поведінки, манерам, які утворюють систему етикету, культурно-національні традиції. Звички передаються через покоління і утворюють традиції, культурні цінності, ціннісні орієнтації, моральні цінності, які впровадив у вивчення культури Е.Дюркгейм, це ціннісні сутички, суперечності в соціально-культурних процесах. О.Конт і Г. Спенсер займалися вивченням питань культури в соціальному житті, що культура формується зигзагоподібними формами, стрибками від одних видів культури до різних видів і навпаки. Тому сьогодні ми можемо сказати, що їхнє вчення зберігає актуальність і зараз, але потребує соціологічного вивчення (Tancher, 2013, pp. 165-171).

\section{Аналіз останніх досліджень і публікацій}

Проблема культури розглядається в різних аспектах $\mathrm{i}$ різними дослідниками збоку вивчення національної культури і привертає увагу багато сучасних вчених, зокрема О. Колесник, А.Арнольдов, а 3 боку сучасного вивчення культури як соціокультурного феномену Ю. Аротюнян, М. Шульга, А. Ручка, В. Танчер, а серед зарубіжних дослідників А. Гіденс, Дж. Александер, У. Бек.

\section{Формулювання мети і завдань статті}

Головна мета статті полягає у з'ясуванні сутності, еволюції розвитку культури, соціальних напруженностей в соціокультурному просторі та 
проаналізувати нові соціальні зміни культурних комунікацій, ролі та культурні прояви.

\section{Наукова новизна дослідження}

В статті аналітично досліджено природу видів понять культурної комунікації та мультикультуралізму з боку соціальних напруг у культурній сфері та увага приділяється вивченню двох напрямків проблем культури соціальному та культурологічному.

\section{Виклад основного матеріалу дослідження}

У нашому полікультурному суспільстві виникають розбіжності стосовно різних культур, їх традицій, звичок і відношення до них. Світосприйняття культури відбувається на генетичному рівні і вона розвиває національну приналежність до культури, тобто формуються «культурні коди». Культурологи вивчають це питання досконало і сьогодні воно ще залишається відкритим для різних досліджень. Для налагодження культурного життя треба збалансувати глобалізацію до позитивного, локального, універсального у світовому культурному розвитку (Tancher, Skokova, 2010, pp. 35-60).

Процес глобалізації проходить через глобалізаційні мережі всіх культурних символів, кодів, шаблонів. Завдяки глобалізації ми можемо одночасно володіти будь-якою інформацією світу через Інтернет отримуємо новини реклами, політичних подій, екологічних катастроф, різних шоу, телепрограм, курсів валют, біржові, банківські операції, покупки он-лайн та ін., тобто всі живуть у вирію однакових подій, формується лінійний культурний глобалізаційний розвиток особистості (Tancher, 2013, pp. 165-171).

Поняття «глобальна культура» вживається в процесі глобалізації в галузі культури. Постає негайне питання захисту культурного розмаїття в Україні й світі. Будь-яка держава і Україна, зокрема, не в змозі контролювати потоки культурних зразків, ідей, штампів, які приходять до нас через кордон та соціальну мережу (Інтернет, Фейсбук та ін.). I як зазначив відомий соціолог А. Ручка, в процесі глобалізації $є$ і негативні сторони, які ведуть до типовості, однобічності, до західних взірців культури. I перевага та надання важливішого значення надається саме закордонним зразкам культури над зразками національними (Ruchka, 2003, pp.13-17). Є проблема виникнення між націокультурною ідентичністю та процесу глобалізації. Але в наш час ця картина трохи змінилася на краще, це спонукало через національні інтереси пов'язані з воєнними діями на Сході країни. Стало модно бути українцем і носити українське, національні орнаменти, символіку вишиванки та жовто-сині кольори стали застосовувати не тільки на території України, а в скрізь в світі, в побуті, одязі, мистецтві, живописі та ін. Таким чином глобальне і локальне переплелося в світовому культурному процесі. Соціальний напрям глобалізації і потребі національної ідентичності потребують соціологічного вивчення. 
У. Бек вважає, що глобалізаційний погляд на культуру поєднує повагу до культурної інакшості породжуючи спільну динаміку культурного розвитку (Tancher, 2013, pp. 165-171). Тому поняття «глокалізація» входить в поняття «глобальна культура», перспектива в локальних умовах. Це i $\epsilon$ локальна культура для вироблення культурних продуктів на глобальному рівні, товари для туристів, товари національної символіки, народної культури, які характеризують побут, культуру тієї чи іншої держави. Всі їздять за кордон і хочуть привести сувенір, який охарактеризував би саме культурний символ країни.

Українське суспільство багатонаціональне, полікультурне, має запозичені культурні взірці світових мистецьких надбань західноєвропейська модель, американська модель. Усі ці моделі мають свої недоліки й переваги, але для нас актуальні саме європейські практики з урахуванням того, що Україна ввійшла в $Є C$, але $€$ недолік - це проблема в полікультуралізмі, саме він і веде весь культурний розвиток в Україні. Особливості полікультурності в Україні полягають в тому, що домінуючою культурою в нашій країні $\epsilon$ західна, а не національна культура (Tancher, Skokova, 2010, pp. 36-60). Змагання та суперництво двох напрямків культури не сприяє їх розвитку, це випливає з політичних ситуацій, несумісних векторів розвитку країни, але з огляду на соціальні напруження, які є в державі, то вони не виглядають проблемними. Знаходять контакти між собою. Такий вид культури називається акультурація. Це поняття вперше започаткували американські науковці М. Герсковіц, Р. Редфілд, (Sakharchuk, 2009, pp. 314-317) вони показали, що з соціальними змінами в суспільстві відбуваються зміни в акультурації, які відбувалися завдяки культурному відтворенню, але сьогодні це поняття розглядається набагато ширше. Акультурація масштабно впроваджує зміни, які відбуваються в структурних елементах культури суспільства. Вона виникає, коли є нерівноправні культури, де одна сильніша іншої і може асимілювати їі. Це дуже ускладнює культурну комунікацію в суспільстві і передачу культурного наслідування, засвоєння цінностей їх рідної, корінної чи титульної культури від старшого покоління до молодшого покоління, і тоді активно приживаються, залучаються культурні цінності. Такий напрям у культурі називається інкультурація. Американський науковець М. Герсковіц, (Sakharchuk, 2009, pp. 314-317) започаткував це поняття, і ми про нього згадували вище, він відносив його до процесу наслідування культури поколіннями. Це наслідування продовжується протягом всього свідомого життя людини й відбувається засвоєння культурних елементів. Тобто, особистість проходить процес соціалізації, який винайшов американський соціолог Ф. Гіденс. Це поняття активно використовується в соціологічній науці, особистість засвоює поступово культурні норми, цінності на кожній фазі свого 
розвитку. I за все життя збирає доволі великий і різносторонній багаж культурного наслідування (Giddens, 1990). Ці два поняття близькі один до одного, протікають одночасно. Процес соціалізації охоплює набуття та присвоєння навиків, норм та ролей, які відтворюються в рамках того чи іншого суспільства, також відбувається миттєве наслідування культурних елементів, виховання особистості в рамках культури, самовиховання за допомогою інших людей, груп соціалізації. Завдяки первинній соціалізації складається базовий процес розвитку індивіда і вторинній соціалізації, де особистість під їх впливом безпосередніх контактів і інституцій входять у багатоманітні культурні процеси. Поняття інкультурація тотожне поняттю культурній трансмісії, де базисна культура передається від поколінь до поколінь саме через навчання і не переривається в часі. Тобто, культурна трансмісія, яка розвивається в часі й частина минулої спадщини зберігається в теперішній час (Ruchka, 2002). Якщо життя людей стрімко змінилося з соціальним розвитком суспільства чи соціальними змінами, змінами культурних носіїв, то відбувається розрив культурного ланцюга. У даний час культурна трансмісія розвивається завдяки засобам масової комунікації й соціальних мереж. Відбувається контакт між виробниками культурних продуктів і споживачами цих продуктів (активними користувачами соціальних мереж та 3MI). Завдяки Інтернету, культурні елементи можуть споживати великі маси людей, тобто цей вид культури розрахований на масову культуру, де культурного контакту з виробником культурного елементу не відбувається, такий підхід надає нам процес інкультурації.

Отже, роблячи короткий аналіз всіх понять, які дуже схожі за змістом, вони нерідко ототожнюються і змінюються, але потрібно враховувати, що існують певні нюанси в розгляду цих понять.

Для підтвердження вище зазначеного використовуємо дані включно до 2016 року соціологічного моніторингу українського суспільства, який був проведений Інститутом соціології НАН України. Нижче наведено приклади в Таблиці 1, стосовно того, як залучені люди в дозвіллєвій сфері і проходить їх динаміка процесу соціалізації чи інкультурації, акультурації за періоди 1994-2016 pp. (Vorona, Shulga, eds. 2016, pp. 489-492). У таблиці (скорочена) наведено багато ознак, які формуються в особистості в процесі життя саме через наслідування. Саме відвідування театрів, концертів, музеїв, художніх виставок людина прививає через акультурацію і соціалізацію, яке пов'язане через сім'ю і це становило на 1994 рік 34 \% опитаних, а на 2016 рік 22 \%, тобто культурна комунікація високо зросла в попиті населення.

У таблиці зображено, що певні ознаки залишаються такими ж самими в динаміці, серед них («Поїздка за місто для відпочинку на природі» - стабільно становить протягом всього моніторингу з 1994-2016 рр. - 22 \%, «Екскурсійна 
подорож» - $3 \%$, «Відвідування спортивних видовищ (як глядач)» - $3 \%$, «Відвідування кінотеатру» - 7 \%, «Відвідування театрів, концертів, музеїв, художніх виставок» - 4\%, а є ознаки, до яких зменшився інтерес «Відвідування бібліотек» - $37.2 \%$ зменшилося на 4,1\%, «Читання художньої літератури» з 37,7 \% зменшилося на 16.9 \% (Vorona, Shulga, eds. 2016, pp. 489-492).

Таблиця 1

\begin{tabular}{|c|c|c|c|c|c|c|c|c|}
\hline & 1994 & 1998 & 2000 & 2004 & 2006 & 2010 & 2014 & 2016 \\
\hline $\begin{array}{l}\text { Поїздка за місто для відпочинку на } \\
\text { природі }\end{array}$ & 21.5 & 18.2 & 8.7 & 9.5 & 13.3 & 12.6 & 18.5 & 22.0 \\
\hline Екскурсійна подорож & 2.9 & 2.3 & 1.7 & 0.4 & 1.5 & 1.4 & 2.1 & 3.2 \\
\hline $\begin{array}{lll}\begin{array}{l}\text { Biдвідування } \\
\text { (як глядач) }\end{array} & \text { спортивних } & \text { видовищ } \\
\end{array}$ & 3.8 & 4.0 & 3.2 & 2.1 & 3.1 & 2.4 & 1.6 & 3.2 \\
\hline Відвідування кінотеатру & 7.9 & 1.5 & 1.4 & 2.7 & 4.3 & 4.7 & 4.1 & 6.7 \\
\hline $\begin{array}{l}\text { Відвідування театрів, концертів, музеїв, } \\
\text { художніх виставок }\end{array}$ & 3.4 & 3.9 & 4.1 & 2.2 & 2.9 & 3.6 & 2.3 & 4.7 \\
\hline Відвідування бібліотек & 7.2 & 5.9 & 5.9 & 4.9 & 5.1 & 3.7 & 2.7 & 4.1 \\
\hline Читання художньої літератури & 37.7 & 35.0 & 39.0 & 26.7 & 24.1 & 21.1 & 16.9 & 16.9 \\
\hline $\begin{array}{l}\text { Художня творчість (створення музики, } \\
\text { віршів, прози, малювання, гра на } \\
\text { музичних інструментах тощо) }\end{array}$ & 4.5 & 3.5 & 4.9 & 2.3 & 3.1 & 2.7 & 2.9 & 2.6 \\
\hline 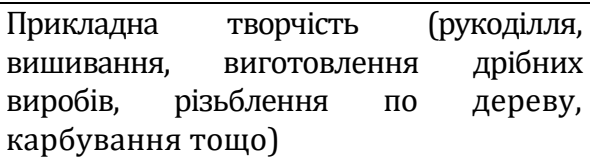 & 12.9 & 9.2 & 10.6 & 6.9 & 5.6 & 4.6 & 4.7 & 6.0 \\
\hline $\begin{array}{l}\text { Прослуховування музики } \\
\text { диски, магнітозаписи) }\end{array}$ & 32.4 & 32.9 & 34.5 & 25.6 & 27.7 & 26.0 & 21.0 & 22.6 \\
\hline $\begin{array}{l}\text { Відвідування } \quad \text { церкви } \\
\text { синагоги, мечеті, молитовного дому) }\end{array}$ & 14.4 & 14.0 & 22.7 & 14.2 & 16.8 & 27.6 & 16.2 & 18.7 \\
\hline 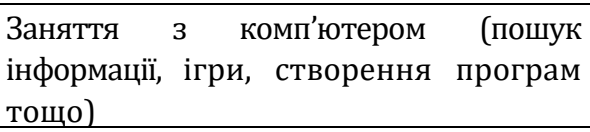 & 4.7 & 6.6 & 5.4 & 7.4 & 15.6 & 20.3 & 32.1 & 36.3 \\
\hline Перегляд телепередач & 79.2 & 80.1 & 86.5 & 83.3 & 87.4 & 86.6 & 75.6 & 72.5 \\
\hline Прослуховування радіопередач & 47.3 & 50.2 & 58.2 & 38.8 & 50.4 & 32.7 & 23.8 & 22.8 \\
\hline Читання газет & 53.6 & 61.9 & 70.3 & 58.3 & 66.6 & 51.9 & 33.9 & 29.6 \\
\hline Просто відпочинок, нічого не роблячи & 42.9 & 39.0 & 43.5 & 41.0 & 42.2 & 42.3 & 44.3 & 43.6 \\
\hline
\end{tabular}

Джерело: Див. Табл. 1 (Vorona, Shulga, 2016, pp. 489-492)

Прояв національної приналежності до культурного елемента завдяки прикладній творчості (рукоділля, вишивання, виготовлення дрібних виробів, різьблення по дереву, карбування) становить у 1994 р. 12,9 \%, а в 2016 році 6 \%, це показує, культурний ланцюг до вподобань національної культури дуже 
послаб, пріоритети були поставлені на запозичені елементи західної культури (Vorona, Shulga, 2016, pp. 489-492).

3 огляду на дані, які розміщені в Табл. 1. можемо зауважити, що багато перелічених позицій не використовували в ті часи активно, вони почали активізуватися з 2002 року, тобто з'явилися нові коди культурної комунікації. Станом 2016 року видно з таблиці, що в середньому показники у відсотках зменшилися по привабливості тих чи інших занять у дозвіллєвій сфері людини, це говорить про те, що гаджети, комп'ютери, мобільні телефони (36,3%), телебачення $(72,5 \%)$ заполонили і створили важливу нішу в культурному житті та розвитку особистості. У середньому за всіма ознаками спостерігаємо, що $є$ певна схожість і відмінність в дозвілевих практиках, але пасивний відпочинок займає значне місце (43,6 \%) (Vorona, Shulga, eds. 2016, pp. 489-492).

\section{Висновки}

Усе вище зазначене надає змогу зробити висновок того, що прослідковуються різні смаки та взірці культурної комунікації різних культурних світів і процес інкультурації обмежений i набагато менший за процес акультурації, це підтверджується в Таблиці 1. Глобалізація насаджує нам життєві моделі, смаки, потреби, а національна культура залишається спиратися на традиційні зразки і черпає звідси свою ідентичність. Одні сприймаються зразки, а інші ні, яке призводить до соціальної напруженості. Соціальне напруження, притаманне для будь-якого суспільства. Культурні протиріччя, які посилюють соціальну напругу призводять до конфліктів усуспільстві і зростання навантаження на національний культурний ланцюг.

\section{References:}

1. Giddens, A. (1990). The Consequence of Modernity. Stanford: Stanford University Press.

2. Ruchka, A. ed. (2002). Sotsiokulturni identychnosti ta praktyky Sotsiokulturni identychnosti ta praktyky [Sociocultural identities and practices]. Kyiv: Institute of Sociology of the National Academy of Sciences of Ukraine.

3. Ruchka, A. A. (2003). Kul'turnye sostavlyayushchie obshchestvennoi svyazi [Cultural Components of Public Communication]. Visnyk Kharkivskoho natsionalnoho universytetu imeni V. N. Karazina. Seriia: Sotsiolohichni doslidzhennia suchasnoho suspilstva: metodolohiia, teoriia, metody [Bulletin of Kharkiv National University named after V. N. Karazin. Sociological Researches of Modern Society: Methodology, Theory, Methods], no. 577, pp. 13-17.

4. Sakharchuk, L. I. (2009). Sotsializatsiia, inkulturatsiia ta akulturatsiia movtsiv $\mathrm{u}$ informatsiinomu multykulturnomu suspilstvi [Socialization, inculturation and acculturation of speakers in the information multicultural society]. Problemy 
semantyky slova, rechennia ta tekstu [Problems of semantics of words, sentences and text], issue 22, pp. 314-317.

5. Tancher, V. V. (2013). Multykulturni problemy sotsialnoho svitu, shcho hlobalizuietsia [Multicultural problems of a globalized global socializing]. Kulturolohichna dumka [Culturological Thought], no. 6, pp. 165-171.

6. Tancher, V. V., Skokova, L. G. (2010). Smyslotsentrovanyi pidkhid kulturalnoi sotsiolohii [Center of thought approach of cultural sociology]. Sotsiolohichni doslidzhennia kultury: kontseptsii ta praktyky [Sociological studies of culture: concepts and practices]. Kyiv: Institute of Cultural Studies of National Academy of Arts of Ukraine.

7. Vorona, V. M., Shulga, M. O. eds. (2016). Ukrainske suspilstvo: monitorynh sotsialnykh zmin [Ukrainian society: monitoring of social change], pp. 489-492. Kyiv: Institute of Sociology of National Academy of Sciences of Ukraine. Available at: http://i-soc.com.ua/ua/edition/ukrainske-suspilstvo/issues/.

(C) Шевель І. П., 2020 